\title{
Multiple splice variants of the pituitary adenylate cyclase-activating polypeptide type 1 receptor detected by RT-PCR in single rat pituitary cells
}

\section{Bresson-Bépoldin, M-C Jacquot, W Schlegel and S R Rawlings}

Fondation pour Recherches Médicales, University of Geneva, 64 Avenue de la Roseraie, 1211 Geneva, Switzerland.

(Requests for offprints should be addressed to L Bresson-Bépoldin, Laboratoire de Neurophysiologie, CNRS UMR 5543, Université de Bordeaux II Victor Segalen, 146 Rue Léo Saignat, 33076 Bordeaux Cedex, France)

(S R Rawlings is now at Life Science Resources, Abberley House, Graham's Road, Great Shelford, Cambridge CB2 5LQ, UK)

\begin{abstract}
Alternative splicing of the rat type 1 pituitary adenylate cyclase-activating polypeptide (PACAP) receptor (PVR1) produces variants that couple either to both adenylyl cyclase (AC) and phospholipase C (PLC) (PVR1 short, PVR1 hop, PVR1 hiphop), or to AC alone (PVR1 hip). We have previously shown that populations of clonal $\alpha$ T3-1 gonadotrophs express PVR1 hop and PVR1 short mRNAs, whereas clonal $\mathrm{GH}_{4} \mathrm{C}_{1}$ somatotrophs do not. Here we have used the single cell RT-PCR technique to investigate whether normal rat gonadotrophs and somatotrophs express PVR1 mRNA, whether a single cell co-expresses multiple splice variant forms, and whether differential PVR1 mRNA expression correlates with differences in PACAP-stimulated $\mathrm{Ca}^{2+}$ signalling. We found that individual rat gonadotrophs expressed mRNA either for PVR1 hop, for PVR1 short, or
\end{abstract}

co-expressed the two forms. Although we found no differences between the splice variant(s) expressed and the characteristics of PACAP-stimulated $\mathrm{Ca}^{2+}$ responses, the expression of PVR1 mRNA is consistent with the known PACAP stimulation of the PLC system in gonadotrophs. Individual rat somatotrophs also expressed PVR1 hop or PVR1 short (but not PVR1 hip) mRNAs although these forms were never co-expressed. The expression of PVR1 mRNA in somatotrophs can explain in part the activation by PACAP of the AC system in such cells. In conclusion, the single cell RT-PCR technique was used to demonstrate expression of multiple PVR1 splice variants in single identified pituitary cells. These findings open up important questions on the role of alternative splicing in cell biology.

Fournal of Molecular Endocrinology (1998) 21, 109-120

\section{INTRODUCTION}

Pituitary adenylate cyclase-activating polypeptide (PACAP) was originally isolated from ovine hypothalami by its potent ability to stimulate cAMP production in rat anterior pituitary cells. It is a 38 amino acid polypeptide (PACAP38), which also exists as an N-terminally shortened 27 amino acid form (PACAP27), and shares significant sequence homology with vasoactive intestinal polypeptide (VIP) (Arimura 1992). Its wide tissue distribution suggests a variety of physiological roles (Arimura 1992, Christophe 1993), although one of the major functions of PACAP is probably as a hypothalamic factor regulating anterior pituitary cell function (Rawlings \& Hezareh 1996). There appear to be three major target cells for PACAP action in the anterior pituitary gland: the gonadotroph, the somatotroph, and the non-endocrine folliculo-stellate (FS) cell (Rawlings \& Hezareh 1996). In gonadotrophs, PACAP modulates both basal and luteinizing hormone (LH)-releasing hormone (LHRH)stimulated LH synthesis and release (Culler \& Paschall 1991, Tsujii et al. 1994), and in somatotrophs, PACAP stimulates the synthesis and release of growth hormone (GH) (Goth et al. 1992, Velkeniers et al. 1994). PACAP also acts on FS cells to stimulate interleukin-6 release (Tatsuno et al. 1991). 
The actions of PACAP are mediated through at least three receptor subtypes belonging to the secretin/glucagon superfamily of seven transmembrane, G-protein-coupled, receptors (Segre \& Goldring 1993, Rawlings \& Hezareh 1996). The three receptor subtypes can be distinguished, at least in part, by their relative specificity for PACAP versus VIP, and their coupling to different intracellular messenger pathways (Rawlings \& Hezareh 1996). The PACAP/VIP type 1 receptor (PVR1) (also known as PACAP-R or PACAP1) binds PACAP with 100- to 1000-fold higher affinity than VIP. As a result of alternative splicing, the PVR1 exists in four major splice variant forms determined by the presence or absence of inserts in the putative third intracellular loop sequence of the receptor (Spengler et al. 1993), a crucial domain for G-protein coupling (Huang et al. 1996). In addition to the short (insert-less) variant of the receptor (PVR1 short), there are two variants containing one of two possible 28 amino acid inserts termed hop and hip (PVR1 hop, PVR1 hip), and a fourth variant containing both inserts (PVR1 hiphop) (Spengler et al. 1993). Whereas the PVR1 short, PVR1 hop and PVR1 hiphop couple to the activation of both adenylyl cyclase (AC) and phospholipase C (PLC), the PVR1 hip couples to the activation of AC, but not PLC (Spengler et al. 1993). The other PACAP/VIP receptor subtypes, PVR2 (or VIP1-R or PACAP/VIP1-R) and PVR3 (or VIP2-R or PACAP/VIP2-R), exhibit no specificity for PACAP over VIP, and are coupled to the activation of AC, but apparently not PLC (Ishihara et al. 1992, Lutz et al. 1993, Rawlings \& Hezareh 1996).

Binding studies have suggested a predominance of a PACAP-preferring (PVR1-like) receptor in the rat anterior pituitary gland (Gottschall et al. 1990), although the mRNAs for all three PACAP/VIP receptor subtypes have been demonstrated in this tissue (Spengler et al. 1993, Rawlings et al. 1995, Hezareh et al. 1996a). However, these receptor subtypes are differentially expressed in gonadotroph-like (PVR1 and PVR3), somatotrophlike (PVR3) and corticotroph-like (PVR2 and PVR3) cell lines (Rawlings et al. 1995, Hezareh et al. 1996a). Functional studies also suggest a differential expression of these receptor subtypes in normal rat pituitary cells. In rat gonadotrophs, PACAP is significantly more potent than VIP in modulating LHRH-stimulated LH release (Culler \& Paschall 1991), and in stimulating the mobilization of intracellular $\mathrm{Ca}^{2+}$ stores through an inositol trisphosphate $\left(\operatorname{Ins}(1,4,5) \mathrm{P}_{3}\right)$-dependent mechanism (Rawlings et al. 1994, Hezareh et al. 1996b), results suggesting the expression of the PVR1 in this cell type (Rawlings 1996). In rat somatotrophs, PACAP raises cytoplasmic free $\mathrm{Ca}^{2+}$ concentration $\left(\left[\mathrm{Ca}^{2+}\right]_{\mathrm{i}}\right)$ through a cAMP-dependent, but $\operatorname{Ins}(1,4,5) \mathrm{P}_{3^{-}}$ independent, mechanism (Rawlings et al. 1993, Hezareh et al. 1996a, Rawlings 1996). The most likely explanation of these findings is that, as for clonal somatotroph-like $\mathrm{GH}_{4} \mathrm{C}_{1}$ cells (Rawlings et al. 1995, Hezareh et al. 1996a), normal rat somatotrophs express the PVR3. Alternatively, rat somatotrophs could express the PVR1 hip or PVR2, receptor subtypes, which, like the PVR3, are coupled to the activation of AC, but not PLC (Rawlings \& Hezareh 1996). The purpose of the present study was to determine the expression of the PVR1 splice variant forms in normal rat gonadotrophs and somatotrophs. Furthermore, we addressed the question as to whether multiple PVR1 mRNA splice variants were expressed in different cell populations or in the same cell.

In the absence of specific PVR1 antibodies or antagonists, we have adapted the technique of reverse transcription-polymerase chain reaction (RT-PCR) to determine the expression of mRNA for the PVR1 and its splice variants in single identified rat gonadotrophs and somatotrophs (Monyer \& Lambolez 1995, O’Dowd \& Smith 1996). We have clearly shown the expression of multiple splice variants of the PVR1 mRNA in both rat gonadotrophs and somatotrophs. We have thus demonstrated the applicability of this technique to the study of the expression of multiple mRNA transcripts in identified anterior pituitary cells. Furthermore, the functional consequence of the expression of a particular protein mRNA can be determined using microfluorimetric (or electrophysiological) recordings in the same cell.

A preliminary report of this work has been previously published in abstract form (Bépoldin et al. 1996).

\section{MATERIALS AND METHODS}

\section{Preparation of anterior pituitary cells}

The anterior pituitary cell preparation has been described in detail elsewhere (Rawlings et al. 1994). In brief, for each experimental day, cells were prepared from the anterior pituitary gland of a single male Sprague-Dawley rat by trypsin dissociation. Cells were then plated onto poly-L-lysinecoated coverslips in RPMI medium, and incubated at $37^{\circ} \mathrm{C}$ in a humidified atmosphere containing $5 \%$ $\mathrm{CO}_{2}$. Experiments were performed between 2 and $10 \mathrm{~h}$ following cell dissociation. 
$\mathbf{A}$

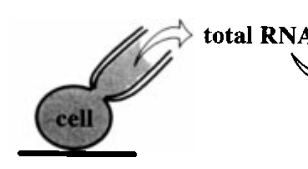

REVERSE TRANSCRIPTION ${ }^{5}={ }^{\prime} \cdot \operatorname{cDNA}$
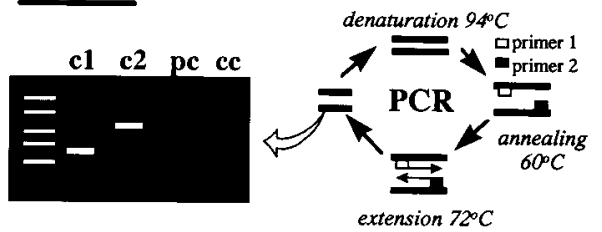

B

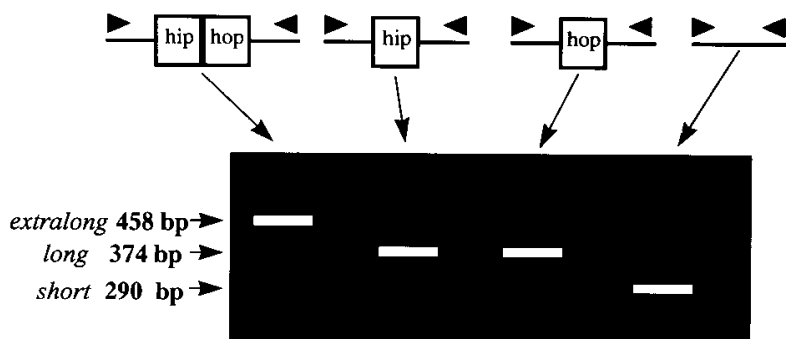

FIgure 1. (A) The single cell RT-PCR technique. The content of a single identified cell is collected with a patch pipette and transferred to a PCR tube, where the total cellular RNA undergoes RT to produce cDNA. A $\mathrm{PCR}$ is then performed using specific primers to amplify the cDNA sequence of interest. Two rounds of PCR (nested PCR) are generally used to produce sufficient material for analysis (not shown). The results of the PCR amplification are analysed by agarose gel electrophoresis. Specificity of the products is confirmed by Southern blot analysis (not shown). (B) Careful PCR primer choice allows co-amplification of multiple PVR1 mRNA splice variant forms. PCR primers (black triangles) are chosen that hybridize to sequences flanking the region of the PVR1 in which alternatively spliced cassettes are inserted. The PCR products are subsequently separated on an agarose gel and the different PVR1 mRNA splice variant forms can be identified by their size and by Southern blot using PVR1 mRNA splice variant-specific probes (see Figs 3 and 4).

\section{Overview of the single cell RT-PCR technique}

Single rat gonadotrophs or somatotrophs were selected on their morphological characteristics and their $\mathrm{Ca}^{2+}$ response to cell-specific agonists. An identified cell was then collected using a patch clamp pipette and expelled into a PCR tube, where its RNA was reverse transcribed into cDNA (Fig. 1). A sample of this reaction then underwent two rounds of PCR using PVR1- or $\beta$-actin-specific primers. The PCR products were visualized using ethidium bromide staining following agarose gel electrophore- sis. Southern blot analysis of the PCR products with splice variant-specific oligonucleotide probes was used to identify the PVR1 splice variants found.

\section{Cell identification}

The rat anterior pituitary gland contains at least six different cell types. For the gonadotroph studies, relatively large (10-12 $\mu \mathrm{m}$ diameter) lobed cells were selected since a high proportion of such cells have been shown to be LH-secreting gonadotrophs (Rawlings et al. 1991). In the present study, greater than $95 \%$ of the cells selected in this way demonstrated a specific $\mathrm{Ca}^{2+}$ response to LHRH (see Fig. 2A). For the somatotroph studies, slightly smaller $(8-10 \mu \mathrm{m})$ round cells were selected, which under phase contrast optics demonstrated a distinct phasebright ring probably corresponding to the high level of secretory granules found in these cells. Approximately $80 \%$ of cells selected by this criterion showed a specific $\mathrm{Ca}^{2+}$ response to $\mathrm{GH}$-releasing hormone (GHRH) (see Fig. 2B). Only cells positively identified by their specific $\mathrm{Ca}^{2+}$ responses to LHRH or GHRH were used in this study.

\section{Calcium measurements}

Changes in $\left[\mathrm{Ca}^{2+}\right]_{\mathrm{i}}$ in single anterior pituitary cells were recorded using the fluorescent $\mathrm{Ca}^{2+}$ indicator indo-1 and microfluorimetry as previously described in detail (Demaurex et al. 1994, Rawlings et al. 1994). Cells were loaded with the membranepermeable ester form of indo-1 (indo-1/AM; $4 \cdot 4 \mu \mathrm{M})$ in standard medium $(127 \mathrm{mM} \mathrm{NaCl}, 5 \mathrm{mM}$ $\mathrm{KCl}, 2 \mathrm{mM} \quad \mathrm{MgCl}_{2}, \quad 1.8 \mathrm{mM} \quad \mathrm{CaCl}_{2}, \quad 5 \mathrm{mM}$ $\mathrm{NaHCO}_{3}, 10 \mathrm{mM}$ glucose, $10 \mathrm{mM}$ Hepes- $\mathrm{NaOH}$, $\mathrm{pH} \mathrm{7.4)}$ for $30 \mathrm{~min}$ at room temperature. After washing, the real time changes in indo-1 fluorescence (at emission wavelengths of 405 and $480 \mathrm{~nm}$ ) in single cells were recorded using classical microfluorimetry on an inverted epifluorescence microscope. The fluorescence values were then made into a ratio $\left(\mathrm{F}_{405} / \mathrm{F}_{480}\right)$, which is proportional to $\left[\mathrm{Ca}^{2+}\right]_{\mathrm{i}}$ (Grynkiewicz et al. 1985). The results in this paper are expressed as fluorescence ratios rather than as absolute $\left[\mathrm{Ca}^{2+}\right]_{\mathrm{i}}$ values. Previous studies have recorded basal $\left[\mathrm{Ca}^{2+}\right]_{i}$ values for rat somatotrophs and gonadotrophs of around $80-200 \mathrm{nM}$, and peak values in response to GHRH and LHRH of 500-750 nM and 1-2 $\mu \mathrm{M}$ respectively (Rawlings et al. 1994, Rawlings 1996).

\section{Harvesting of the RNA of a single cell}

Following a $\mathrm{Ca}^{2+}$ recording, the cytoplasm of the identified cell was collected using an adaptation of 
the patch clamp technique. Patch pipettes (2-4 M $\Omega$ ) were made from ethanol-washed, autoclaved borosilicate glass and filled with $7 \mu$ pipette solution (120 mM K aspartate, $20 \mathrm{mM} \mathrm{KCl,} 2 \mathrm{mM} \mathrm{MgCl}_{2}$, $20 \mathrm{mM}$ Hepes-NaOH, pH 7.4). A high resistance seal was formed between the patch pipette and the cell membrane before the establishment of the whole cell configuration (Hamill et al. 1981). The contents of the cell (including the nucleus and cell membrane) were then aspirated into the pipette by applying gentle suction through the pipette. This was done under visual control to harvest as much of the recorded cell as possible and to avoid collecting neighbouring cells. After cell harvesting, the pipette was withdrawn and its contents expelled into a PCR tube containing the reverse transcription (RT) reaction solution.

\section{Reverse transcription}

The RT reaction was performed on total cell content without any purification. As stated above, the cell content $(4 \cdot 5$ or $5 \mu \mathrm{l})$ was expelled into a PCR tube containing $5 \mu \mathrm{l}$ of the $\mathrm{RT}$ reaction solution composed of: $100 \mathrm{ng}$ random hexamer primers, 10 units recombinant ribonuclease inhibitor, $1 \mathrm{mM}$ (final concentration) of the four deoxyribonucleotides, $10 \mathrm{mM}$ (final concentration) dithiothreitol $(\mathrm{DT} T)$ and $1 \times$ first strand buffer. One hundred units Superscript $\mathrm{RNase}^{-} \mathrm{H}^{-}$reverse transcriptase were then added (giving a total reaction volume of $10 \mu \mathrm{l})$ and the tube was incubated for $1 \mathrm{~h}$ at $37^{\circ} \mathrm{C}$. The reaction was stopped by cooling the tubes on ice and the newly synthesized cDNAs were stored at $-20{ }^{\circ} \mathrm{C}$ until PCR amplification.

\section{Single cell RT-PCR for PVR1 and $\beta$-actin mRNAs}

The first PCR to amplify the PVR1 mRNA (cDNA) was performed in a final volume of $50 \mu$ l containing $5 \mu \mathrm{l}$ of the RT reaction products, $30 \mathrm{pmol}$ of each primer, $200 \mu \mathrm{M}$ of the four deoxyribonucleotides, $1.5 \mathrm{mM} \mathrm{MgCl}_{2}, 5 \mu \mathrm{l} 10 \times \mathrm{PCR}$ buffer and 2.5 units Taq DNA polymerase. The PCR was run for 40 cycles $\left(94{ }^{\circ} \mathrm{C}\right.$ for $30 \mathrm{~s}, 60{ }^{\circ} \mathrm{C}$ for $30 \mathrm{~s}, 72{ }^{\circ} \mathrm{C}$ for $\left.45 \mathrm{~s}\right)$, followed by a final extension step at $72{ }^{\circ} \mathrm{C}$ for $5 \mathrm{~min}$ (Omnigene Thermocycler, Hybaid, Basingstoke, UK). Similar conditions were used for the $\beta$-actin primers, although only $1 \mu \mathrm{l}$ of the RT reaction was used.

The second PCR was performed using $5 \mu$ of the first PCR product as template, $30 \mathrm{pmol}$ of each primer, $200 \mu \mathrm{M}$ of the four deoxyribonucleotides, $1.5 \mathrm{mM} \mathrm{MgCl}_{2}, 5 \mu \mathrm{l} 10 \times \mathrm{PCR}$ buffer and $2 \cdot 5$ units Taq DNA polymerase in a final volume of $50 \mu \mathrm{l}$.
The PCR was run for 35 cycles $\left(94^{\circ} \mathrm{C}\right.$ for $30 \mathrm{~s}$, $60{ }^{\circ} \mathrm{C}$ for $30 \mathrm{~s}, 72{ }^{\circ} \mathrm{C}$ for $30 \mathrm{~s}$ ) followed by a final extension at $72^{\circ} \mathrm{C}$ for $5 \mathrm{~min}$. Similar conditions were used for the $\beta$-actin primers, although only $1 \mu \mathrm{l}$ of the first PCR product was used as template.

Fifteen microlitres of the PCR product were mixed with loading buffer and run on a $2 \%$ agarose gel electrophoresis stained with ethidium bromide.

\section{PCR amplification of cloned PVR1 cDNA}

The coding sequence of the different PVR1 subtypes (short, hip, hop and hiphop) were cloned in pBluescript $2 \mathrm{SK}^{-}$plasmids (kind gift from L Journot). PCR products were produced from $2 \mathrm{ng}$ of the relevant plasmid using the same protocol as for the second round of PCR described above.

\section{Primer selection}

To amplify specific mRNAs (cDNAs) from a single cell we have employed two rounds of PCR with nested PCR primers. Primers were designed using OLIGO primer analysis software (OLIGO version 4.06, National Biosciences Inc., Plymouth, MN, USA) and were obtained from MWG (Biotech, Ebersberg, Germany). To avoid the possibility of amplifying genomic DNA, all primer pairs were chosen to flank at least one intron in the genomic sequences (Nudel et al. 1983, Chatterjee et al. 1997). Table 1 summarizes the primer sequences used.

\section{Southern blot analysis}

Ten microlitres DNA amplified fragment from a single cell cDNA and $3 \mu \mathrm{l}$ PCR product from plasmids were separated on a $3 \%$ agarose gel electrophoresis and transferred by capillarity onto Hybond N membranes (Amersham Life Science, Amersham, Bucks, UK). The membranes were dried for $10 \mathrm{~min}$ at $80^{\circ} \mathrm{C}$, fixed under UV light, prehybridized overnight at $65^{\circ} \mathrm{C}$ in $5 \times \mathrm{SSC}$, $5 \times$ Denhart's solution, $0.5 \%$ SDS and $100 \mathrm{mg}$ salmon sperm DNA, and then hybridized for $2.5 \mathrm{~h}$ at $65^{\circ} \mathrm{C}$ in $5 \times \mathrm{SSC}, 5 \times$ Denhart's solution and $0 \cdot 5 \%$ SDS with 15 pmol of the relevant ${ }^{33} \mathrm{P}$-labelled oligoprobe. The membranes were then sequentially washed with $2 \times \mathrm{SSC}$ and $0 \cdot 1 \% \mathrm{SDS}, 1 \times \mathrm{SSC}$ and $0 \cdot 1 \%$ SDS and finally $0 \cdot 1 \times \mathrm{SSC}$ and $0 \cdot 1 \% \mathrm{SDS}$. The film was exposed at $-80{ }^{\circ} \mathrm{C}$ to the Southern blot membrane for times varying between 24 and $90 \mathrm{~h}$. 
The sequences of the oligoprobes were: 'common probe', 5'-CAC AAG TCT TTC CCT CTT GCT CAC GTT CTC-3' (position 1116-1146) (Spengler et al. 1993); 'hip-specific probe', 5'-TCG GGT TTT CTT GGG GAC 'TCT CAG TCT TAA-3' (position 1147-1177); and 'hop-specific probe', 5'-GGA TAG TTC TGA CAT CTT GCA AGA GTG CTG CTG AGC-3' (position 1261-1297). These probes were labelled with $\left[\gamma_{-}{ }^{33} \mathrm{P}\right] \mathrm{ATP}$ using a polynucleotide kinase.

\section{Controls}

The adaptation of the RT-PCR technique to the detection of mRNA species in single cells required us to address several concerns. First, possible contamination of the solutions with PVR1 cDNA or mRNA was tested for by including a 'pipette control', where the patch clamp pipette was placed next to a cell for 1-2 min (the time normally taken to harvest the cell), and then the pipette contents were subjected to the RT-PCR reaction as normal. Secondly, the possibility of amplifying genomic DNA was negated by designing primers that flanked a sequence containing at least one intron (Table 1), and indeed we never detected expression of PVR1 mRNA in cells where we omitted the reverse transcriptase from the $\mathrm{R} T$ reaction ('cell control'). Thirdly, because there was a discrepancy between the number of cells showing PACAPstimulated $\mathrm{Ca}^{2+}$ responses and the number of cells expressing PVR1 mRNA as detected using the single cell RT-PCR technique, we wished to test for possible variability in the technique. In all cells studied, we have amplified the mRNA for $\beta$-actin (a mRNA which is expressed at a high and relatively stable level in many cell types) to exclude possible variations in cell harvesting or RT efficiency or the integrity of the RNA collected. Only cells shown to express $\beta$-actin mRNA ( $>90 \%$ of cell tested) were used in this study. Finally, to test for the reproducibility of the $\mathrm{PCR}$, we divided the RT reaction for certain cells and performed the same PCR on two different occasions. More than $95 \%$ of cells were shown to be either positive-positive or negative-negative for the two PCRs. Furthermore, there did not appear to be any variation in the pattern of splice variant forms amplified for the two PCRs (data not shown).

\section{Data analysis and presentation}

The results presented here were obtained from cells taken from a total of 15 rats. In general between 5 and 15 positively identified gonadotrophs and/or somatotrophs were obtained for each experimental day. Differences in the calcium response characteristics (see the legend of Table 3 for details) were analysed using the Mann-Whitney U-test with $P \leq 0.05$ being taken as statistically significant. Figures were produced by scanning a photograph of the agarose gels or scanning directly the Southern blot film (Logitech Scanman colour, 300 dpi; FotoTouch Color 1·0, Neuchâtel, Switzerland), and importing the resulting *.tif files into Microsoft Powerpoint (version 7·0).

\section{Materials}

The materials used in the present studies were obtained from the following sources: Taq DNA polymerase (Eurobio, Les Ulis, France); random primers, recombinant ribonuclease inhibitor, deoxyribonucleotides (Promega, Lyon, France); Superscript RNase $\mathrm{H}^{-}$reverse transcriptase, $1 \times$ first strand buffer, DTT, penicillin/streptomycin (Life Technologies SARL, Eragny, France); LHRH, GHRH (Sigma Chemie, Buchs, Switzerland); indo1/AM (Molecular Probes Europe BV, Leiden, The Netherlands); PACAP38 (Novabiochem AG, Basel, Switzerland); polynucleotide kinase (BoehringerMannheim AG, Rot Kreuz, Switzerland); $\left[\gamma-{ }^{33} \mathrm{P}\right]$ ATP (Hartmann Analytic GmbH, Braunschweig, Germany).

\section{RESULTS}

\section{Identification of gonadotrophs and somatotrophs}

Changes in $\left[\mathrm{Ca}^{2+}\right]_{\mathrm{i}}$ were recorded in single rat pituitary cells using the fluorescent $\mathrm{Ca}^{2+}$ probe indo-1 and microfluorimetry. All cells used in this study were positively identified as gonadotrophs or somatotrophs by their specific $\mathrm{Ca}^{2+}$ responses to LHRH or GHRH respectively (see the right-hand sections of the traces shown in Fig. 2A and B).

\section{Single cell expression of PVR1 mRNA and PACAP-stimulated $\mathrm{Ca}^{2+}$ responses in gonadotrophs}

Of 84 cells tested for their $\mathrm{Ca}^{2+}$ response to PACAP38 (100 nM), 71 (85\%) showed an increase in $\left[\mathrm{Ca}^{2+}\right]_{\mathrm{i}}$. These $\mathrm{Ca}^{2+}$ responses were observed as high amplitude oscillations (Fig. 2A), which showed marked inter-cell variability in terms of frequency and maximal amplitude as has been previously described (Rawlings et al. 1993). Among the 71 cells exhibiting PACAP-stimulated $\mathrm{Ca}^{2+}$ responses, PVR1 mRNA expression was detected in $34(48 \%)$ 


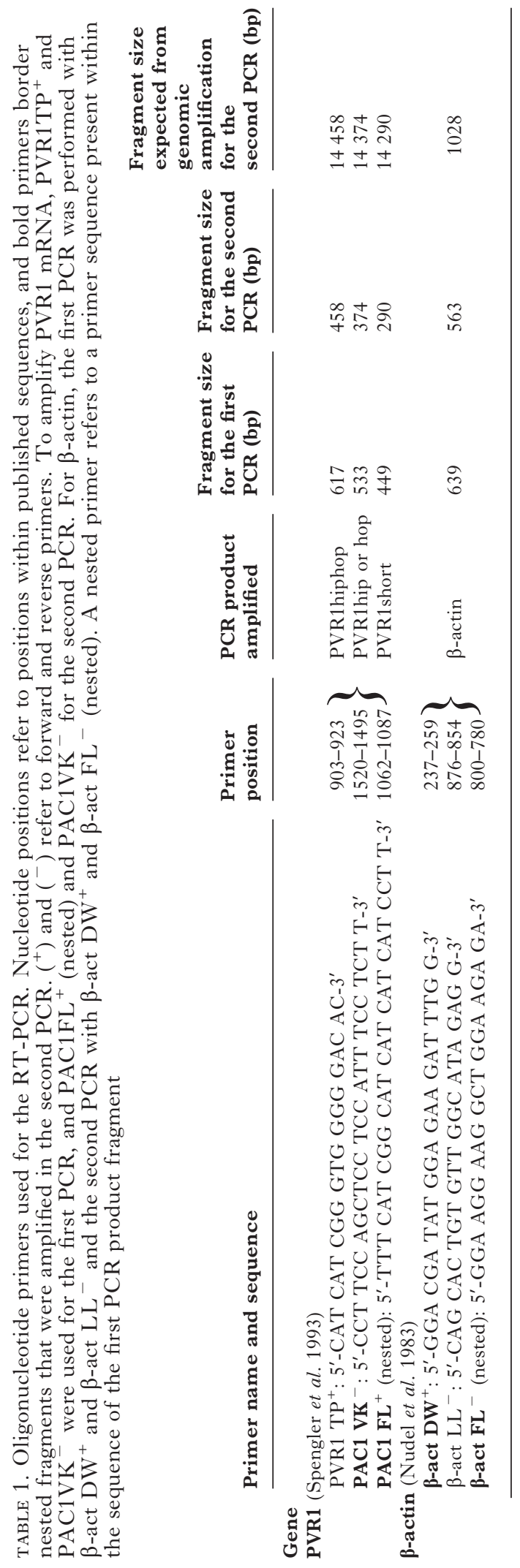



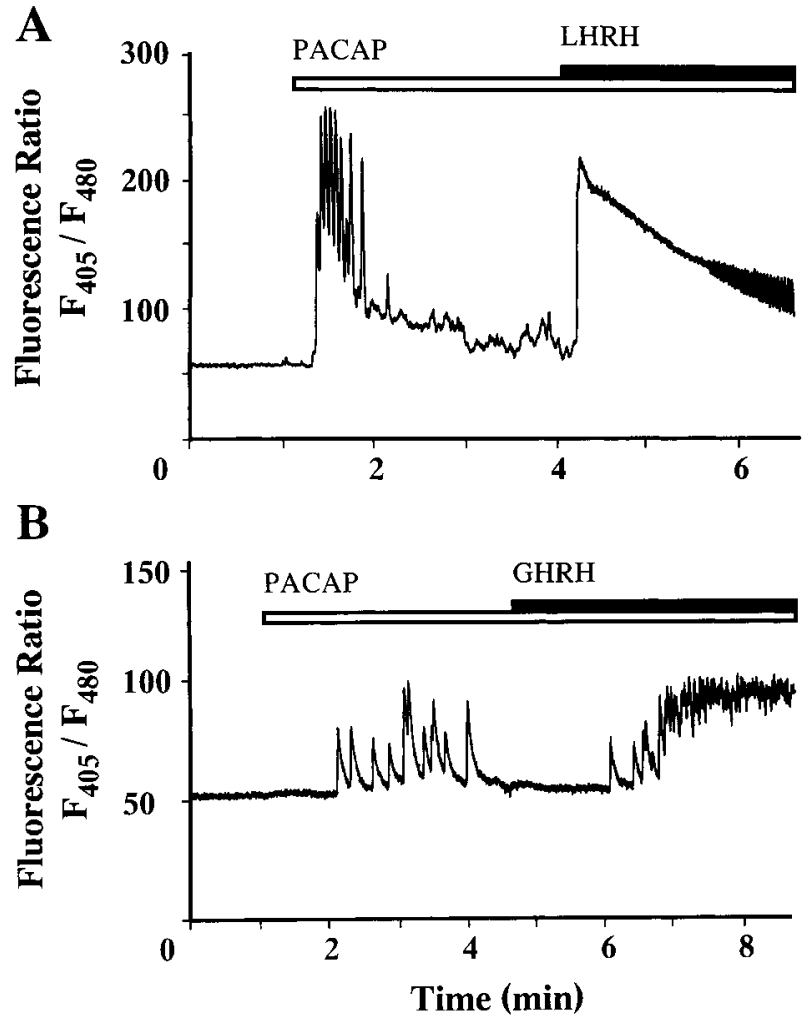

FIGURE 2. Identification of rat gonadotrophs and somatotrophs by their specific $\mathrm{Ca}^{2+}$ responses to $\mathrm{LHRH}$ and GHRH respectively. Changes in fluorescence ratio $\mathrm{F}_{405} / \mathrm{F}_{480}$ (proportional to $\left[\mathrm{Ca}^{2+}\right]_{\mathrm{i}}$ ) of single indo-1-loaded cells were measured by microfluorimetry. Hypothalamic factors were applied as indicated by the bars. Cells were positively identified as a gonadotroph (A) or a somatotroph (B) by their specific responses to LHRH $(10 \mathrm{nM})$ or GHRH $(100 \mathrm{nM})$ respectively. This figure also shows examples of the typical PACAP38 (100 nM)-stimulated high amplitude $\mathrm{Ca}^{2+}$ oscillations in gonadotrophs (A) and PACAP38 (100 nM)-stimulated $\mathrm{Ca}^{2+}$ transients seen in somatotrophs (B).

using the single cell RT-PCR technique. Surprisingly, not all cells expressed the same PVR1 mRNA splice variant forms. Southern blot analysis of the PCR products obtained showed that the majority of the gonadotrophs expressed solely the mRNA for the PVR1 hop form of the receptor, while a smaller proportion expressed mRNA for only the PVR1 short form, or a co-expression of these two forms (Fig. 3; Table 2). In contrast, the proportion of cells exhibiting mRNA for the PVR1 hip and PVR1 hiphop was very low, and indeed the PVR1 hip mRNA was only observed co-expressed with other PVR1 mRNA variants (Table 2). The order of frequency of the expression of the PVR1 mRNA splice variants was: PV-

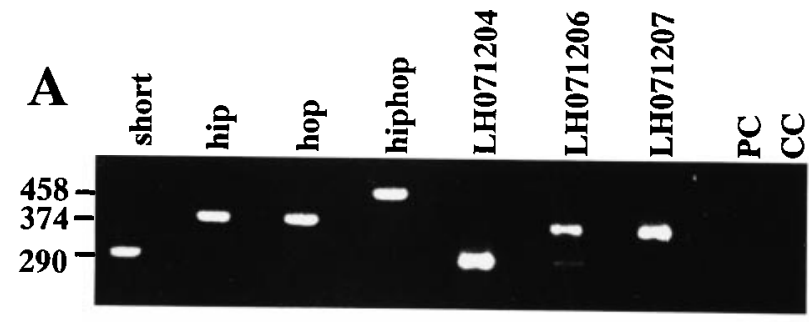

B

common probe

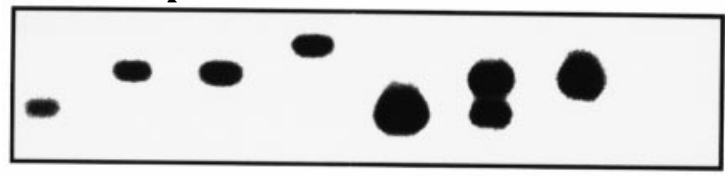

hop-specific probe

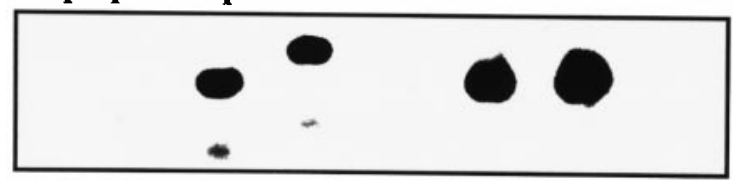

hip-specific probe

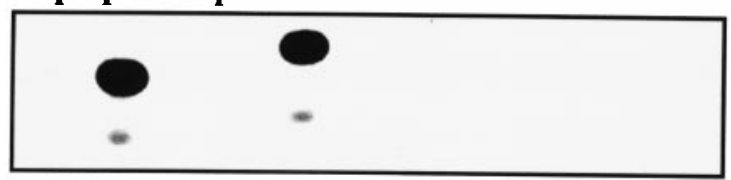

FIGURE 3. PVR1 mRNA splice variant forms are expressed in individual rat gonadotrophs. (A) PCR products separated by agarose gel electrophoresis. PCR products obtained from amplification of $2 \mathrm{ng}$ plasmids containing the sequence corresponding to PVR1 short (short), PVR1 hip (hip), PVR1 hop (hop) and PVR1 hiphop (hiphop). The lanes marked LH071204, LH071206 and LH071207 show PCR products obtained from three single identified gonadotrophs using the single cell RT-PCR technique. The lanes marked PC and CC correspond to the 'pipette control' and 'cell control'. (B) Southern blot analysis of the PCR products shown in (A). Differential hybridization of membranes with selective probes: 'common probe', which hybridizes to a sequence common to all PVR1 splice variants; 'hop-specific probe', which hybridizes specifically to a sequence in the hop insert (therefore hybridizing to both PVR1 hop and PVR1 hiphop); and 'hip-specific probe', which hybridizes specifically to a sequence in the hip insert (therefore hybridizing with PVR1 hip and PVR1 hiphop). In this example, Southern blot confirms the expression of PVR1 short in the gonadotroph LH071204, both PVR1 short and PVR1 hop in the gonadotroph LH071206 and PVR1hop in the gonadotroph LH071207.

R1 hop > PVR1 short $>>$ PVR1 hiphop > PVR1 hip. Thus PVR1 mRNA splice variants are differentially expressed in individual rat gonadotrophs. 
TABLE 2. Distribution of PVR1 mRNA splice variant forms in normal rat gonadotrophs and somatotrophs

Percentage of cells expressing the PVR1 mRNA splice variant forms

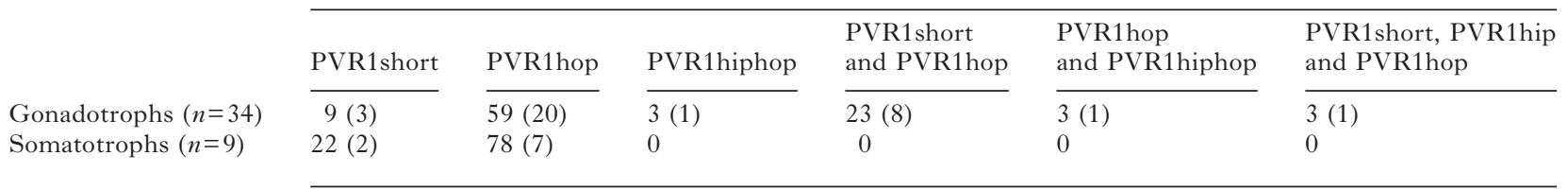

TABLE 3. Characteristics of PACAP38 (100 nM)-stimulated $\mathrm{Ca}^{2+}$ responses in single rat gonadotrophs expressing different PVR1 mRNA splice variants. Delay is the latency between PACAP38 addition and the observation of an increase in $\left[\mathrm{Ca}^{2+}\right]_{\mathrm{i}}$. Maximum amplitude of oscillations is the maximum increase in $\left[\mathrm{Ca}^{2+}\right]_{\mathrm{i}}$ induced by PACAP38 during the first minute of response. This is expressed as the difference $(\Delta)$ of the indo- 1 fluorescence ratio $\mathrm{F}_{405} / \mathrm{F}_{480}$ (proportional to $\left[\mathrm{Ca}^{2+}\right]_{\mathrm{i}}$ ) between the baseline value and the maximum value obtained. Frequency of oscillations is the number of oscillations triggered by PACAP38 during the first minute of the $\mathrm{Ca}^{2+}$ response. Results are expressed as means \pm S.E.M.

\begin{tabular}{lll}
\multicolumn{2}{l}{ Characteristics of the PACAP38-stimulated $\mathbf{C a}^{2+}$ responses } \\
\hline $\begin{array}{l}\text { Delay } \\
(\mathrm{s})\end{array}$ & $\begin{array}{l}\text { Maximum amplitude } \\
\text { of oscillations } \\
\left(\Delta \mathrm{F}_{405} / \mathrm{F}_{480}\right)\end{array}$ & $\begin{array}{l}\text { Frequency of } \\
\text { oscillations } \\
(n / \mathrm{min})\end{array}$ \\
\hline & & \\
$9 \pm 1$ & $1 \cdot 11 \pm 0 \cdot 15$ & $14 \pm 1$ \\
$24 \pm 16$ & $0 \cdot 80 \pm 0 \cdot 25$ & $11 \pm 3$ \\
$7 \pm 3$ & $1 \cdot 39 \pm 0 \cdot 27$ & $13 \pm 4$
\end{tabular}

PVR1 mRNA splice variants expressed in gonadotrophs PVR1hop $(n=16)$ PVR1short $(n=3)$ PVR1short+PVR1hop $(n=5)$

There was no statistically significant difference between the cells expressing mRNAs for PVR1hop, PVR1short. or co-expressing PVR1short and PVR1hop in terms of any of the three parameters tested (Mann-Whitney U-test; $P<0 \cdot 05$ ).

To determine whether the variability in the $\mathrm{Ca}^{2+}$ response patterns was due to differential expression of the PVR1 splice variant forms, we compared the characteristics of PACAP-stimulated $\mathrm{Ca}^{2+}$ responses of cells expressing PVR1 hop with those of cells expressing either the PVR1 short or both the PVR1 short and PVR1 hop mRNAs (Table 3). No significant differences were seen in the features of the $\mathrm{Ca}^{2+}$ responses to PACAP38 between the three groups of cells in terms of response latency (delay), and the frequency or amplitude of the $\mathrm{Ca}^{2+}$ oscillations (Table 3 ). Such results suggest that the $\mathrm{Ca}^{2+}$ response type to PACAP38 in rat gonadotrophs cannot be simply derived from the splice variant form of PVR1 expressed.

\section{Single cell expression of PVR1 mRNA and PACAP-stimulated $\mathrm{Ca}^{2+}$ responses in somatotrophs}

Thirty-four identified somatotrophs were tested for PACAP $\mathrm{Ca}^{2+}$ response. Fifty-three percent (18 of $34)$ of tested cells showed PACAP $\mathrm{Ca}^{2+}$ responses which were characterized by either repetitive $\mathrm{Ca}^{2+}$ transients (Fig. 2B), or step-wise increases in $\left[\mathrm{Ca}^{2+}\right]_{\mathrm{i}}$. The $\mathrm{Ca}^{2+}$ transients differ from the $\mathrm{Ca}^{2+}$ oscillations observed in rat gonadotrophs in that the $\mathrm{Ca}^{2+}$ transients are significantly smaller in amplitude. They differ as well in shape and, as we have shown previously, are exclusively due to $\mathrm{Ca}^{2+}$ influx across the cell membrane and not to mobilization of Ins(1,4,5)P3-sensitive calcium stores (Rawlings et al. 1993, Hezareh et al. 1996b, Rawlings 1996).

PVR1 mRNA expression was tested on these 34 cells. In nine cells $(27 \%)$ we detected the expression of PVR1 mRNA (Fig. 4, Table 2). Six cells exhibited both PACAP $\mathrm{Ca}^{2+}$ responses and PVR1 mRNA expression (four cells expressed PVR1 hop mRNA and two cells PVR1 short mRNA) while three cells expressed PVR1 hop mRNA but did not show PACAP $\mathrm{Ca}^{2+}$ response. We never observed the co-expression of multiple splice variant forms of the receptor in rat somatotrophs as we did in the gonadotrophs (Fig. 3). It is also noteworthy that we never observed the presence of the mRNA encoding PVR1 hip in these cells (Table 2).

\section{DISCUSSION}

This study is the first clear demonstration of the expression of mRNA for the PVR1 and its splice variants in single identified rat gonadotrophs and somatotrophs. Furthermore, the use of single cell RT-PCR has demonstrated not only that different 


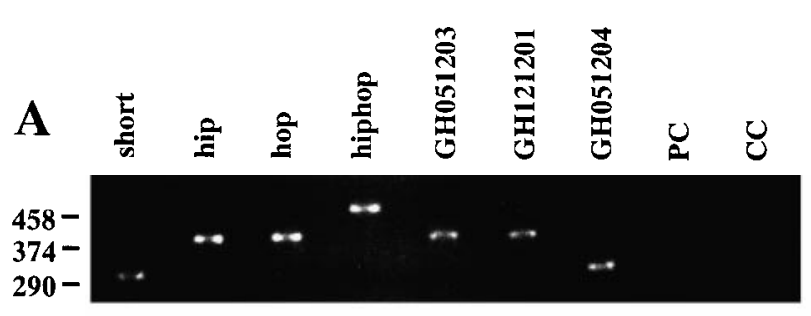

B

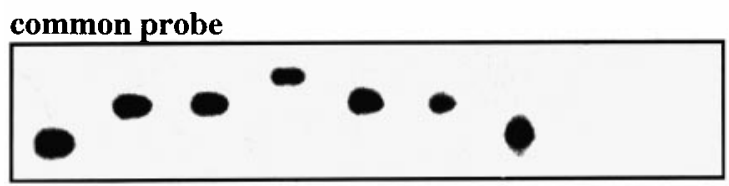

hop-specific probe

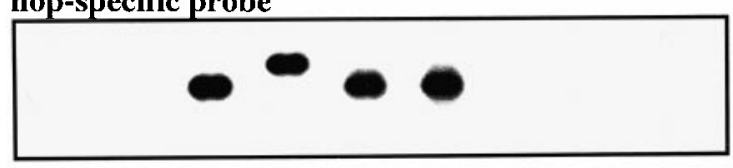

hip-specific probe

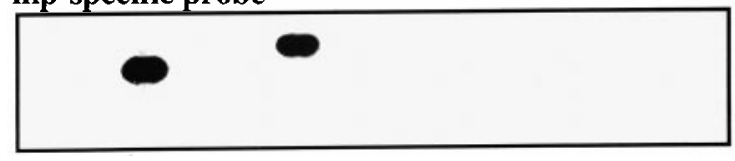

FIGURE 4. PVR1 mRNA splice variant forms are expressed in individual rat somatotrophs. (A) PCR products separated by agarose gel electrophoresis. PCR products obtained from amplification of 2 ng plasmids containing the sequence corresponding to PVR1 short (short), PVR1 hip (hip), PVR1 hop (hop) and

PVR1 hiphop (hiphop). The lanes marked GH051203, GH121201 and GH051204 show PCR products obtained from three single identified somatotrophs using the single cell RT-PCR technique. The lanes marked PC and $\mathrm{CC}$ correspond to the 'pipette control' and 'cell control'. (B) Southern blot analysis of the PCR products shown in (A). Differential hybridization of membranes with selective probes: 'common probe', which hybridizes to a sequence common to all PVR1 splice variants; 'hop-specific probe', which hybridizes specifically to a sequence in the hop insert (therefore hybridizing to both PVR1 hop and PVR1 hiphop); and 'hip-specific probe', which hybridizes specifically to a sequence in the hip insert (therefore hybridizing with PVR1 hip and PVR1 hiphop). In this example, Southern blot confirms the expression of PVR1 hop in the somatotrophs GH051203 and GH051201 and PVR1 short in the somatotroph GH051204.

cells can express different PVR1 splice variants, but also that more than one PVR1 splice variant form may be expressed in a single cell. Such results open questions about the physiology of PACAP action.

\section{Single cell RT-PCR}

In the present study, we have tested the applicability of single cell RT-PCR for the study of mRNA expression in identified anterior pituitary cell types. We initially set up the technique by studying the expression of high abundance mRNA species such as those for $\beta$-actin, $\mathrm{GH}$ and prolactin in clonal pituitary cells. Using the methods described in this paper, we had little problem in detecting such high abundance mRNAs in the majority $(>90 \%)$ of cells tested (data not shown). In contrast, the detection of low abundance mRNAs for a receptor like the PVR1 proved to be more problematic and involved a great deal of work in optimizing the harvesting and RT-PCR conditions to allow reliable detection of such signals. Even so, we only reliably detected the expression of PVR1 mRNA in about half of the gonadotrophs which had demonstrated a PACAP38-stimulated $\mathrm{Ca}^{2+}$ response, although all of these cells exhibited detectable levels of $\beta$-actin mRNA. Such discrepancies have been previously reported with this technique (O'Dowd \& Smith 1996, Poth et al. 1997), and are probably due to the fact that the relatively low PVR1 mRNA copy number is below the threshold for detection in some cells. It is also possible that some of the PVR1 mRNA-negative cells represent a subpopulation of cells that do not express this receptor. By using PCR primer pairs which bind to common PVR1 sequences, thus allowing amplification of all the splice variant forms with similar efficiencies (see the left-hand side of Figs 3A and 4A), we can compare the relative expression of the PVR1 mRNA splice variants in the same cell. Such studies have clearly demonstrated 'sub-populations' of gonadotrophs and somatotrophs in terms of whether they express mRNA for the PVR1 short, PVR1 hop or co-express the two splice variants. Thus, it is clear from these data that single cell RT-PCR can detect low levels of mRNA expression in a significant number of cells, and that the detection of such mRNA can be correlated to the functional consequences of its expression. Furthermore, the use of acutely dissociated normal rat pituitary cells provides us with arguably a more physiological relevant preparation than clonal cells or even normal cells maintained in serum-containing media, where the repertory of PVR subtypes may change with time in culture (Christophe 1993).

\section{Differential expression of PVR1 mRNA splice variant forms in rat gonadotrophs}

This is the first direct demonstration of the expression of PVR1 mRNA in normal rat gonadotrophs. PVR1 hop was the major mRNA splice variant expressed, with fewer cells expressing the 
mRNA short form (PVR1 short) of the receptor. We also observed the co-expression of these two splice variant forms in some cells. These PVR1 splice variant mRNAs have been previously found in populations of rat anterior pituitary cells and in the gonadotroph-like $\alpha \mathrm{T} 3-1$ cell line (Rawlings et al. 1995, Hezareh et al. 1996a); however, this is the first demonstration of their co-expression in single cells. The expression of mRNA for PVR1 hop and PVR1 short in rat gonadotrophs could explain the results from studies on the intracellular signalling pathways activated by PACAP in this cell type. The PVR1 short and PVR1 hop are the principal PVR1 splice variants coupled to the PLC pathway (Spengler et al. 1993), and it has been shown that PACAP activates PLC and $\operatorname{Ins}(1,4,5) \mathrm{P}_{3}$-dependent mobilization of intracellular $\mathrm{Ca}^{2+}$ stores in rat gonadotrophs (Rawlings et al. 1994, Hezareh et al. 1996b, Rawlings 1996). However, what could be the physiological relevance of the co-expression of two different PVR1 isoforms coupled to same transduction systems in the same cell type? In the present study, we found no difference in the characteristics of PACAP38stimulated $\mathrm{Ca}^{2+}$ signalling in cells expressing mRNA for PVR1 hop, PVR1 short or both receptor splice variants, suggesting that there is probably little or no difference at the level of receptor-Gprotein-PLC coupling. Nevertheless, the PVR1 hop possesses a consensus motif for a PKC-dependent phosphorylation site, which is absent in the PVR1 short (Spengler et al. 1993). It has been suggested that in $\alpha \mathrm{T} 3-1$ cells this phosphorylation site could be involved in cross-talk between the intracellular signalling pathways stimulated by LHRH (PLC) and PACAP (AC and PLC) (McArdle \& Counis 1996, Rawlings \& Hezareh 1996). Thus, the expression of the PVR1 hop in these cells could contribute to a fine-tuned regulation of receptor function. The possibility also exists of differential coupling of these receptor splice variants to other signalling pathways, such as the mitogen-activated protein kinase pathway which can be activated by PACAP through a PVR1-like receptor in a variety of cell types (Zhong 1995, Villalba et al. 1997).

\section{PVR1 mRNA expression in rat somatotrophs}

The somatotroph-like $\mathrm{GH}_{4} \mathrm{C}_{1}$ cell line expresses mRNA for the PVR3, but not the PVR1 (Rawlings et al. 1995, Hezareh et al. 1996a). In contrast, pharmacological studies have suggested the presence of a PACAP-preferring (PVR1-like) receptor in human GH-secreting pituitary adenomas
(Robberecht et al. 1993), and a recent RT-PCR study demonstrated the presence of PVR1 mRNA in a somatotroph-enriched pituitary cell population (Vertongen et al. 1995), although it is extremely difficult to draw conclusions from RT-PCR experiments performed on mixed cell populations. The present study is the first clear demonstration of the expression of mRNA for PVR1 in identified rat somatotrophs, with $70 \%$ of such cells expressing PVR1 hop and 30\% expressing PVR1 short. We found no evidence for the expression of PVR1 hip mRNA. The finding of only the PVR1 short and PVR1 hop (coupled to the activation of both AC and PLC (Spengler et al. 1993)) in rat somatotrophs is surprising since PACAP fails to stimulate the mobilization of $\operatorname{Ins}(1,4,5) \mathrm{P}_{3}$-sensitive $\mathrm{Ca}^{2+}$ stores in these cells (Rawlings et al. 1993, Rawlings 1996). What is the explanation for this discrepancy? It is possible that the low rate of detection of PVR1 mRNA in rat somatotrophs (25\% of cells) reflects a low level of expression. If then there is a co-expression of the PVR1 with the PVR3 (and/or PVR2), it could be the latter receptor (coupled to $\mathrm{AC}$ and not PLC) which makes the major contribution to PACAP action in these cells. This would be consistent with PVR3 expression in clonal rat $\mathrm{GH}_{4} \mathrm{C}_{1}$ somatotrophs (Rawlings et al. 1995, Hezareh et al. 1996a), and indeed PVR subtype co-expression has been demonstrated in clonal $\alpha \mathrm{T} 3$ 1 gonadotrophs and AtT20 corticotrophs (Rawlings et al. 1995, Hezareh et al. 1996a). This could be tested in future single cell RT-PCR experiments using PVR3- (or PVR2-) specific primers. A further, intriguing, possibility would be that the PVR1 is not, or is only weakly, coupled to PLC activation in rat somatotrophs. As for the parathyroid hormone receptor, a member of the same receptor superfamily as PVR1 (Segre \& Goldring 1993), the amino acid residues responsible for coupling to $\mathrm{G}_{\mathrm{s}}$ (AC activation) and $\mathrm{G}_{\mathrm{q}}$ (PLC activation) are clustered in a very short region of the third intracellular loop, making it highly unlikely that the receptor could contact the two G-proteins at the same time (Huang et al. 1996). Thus, if the somatotroph expresses an excess of $G_{s}$ compared with $G_{\mathrm{q}}$, the $G_{\mathrm{s}}$ proteins would preferentially occupy the receptor-G-protein binding site, effectively producing a PVR1 that functionally couples only to $G_{s}$ and $A C$ activation. This effect would be cell dependent, and would not be observed in transfection studies, where the receptor (and therefore the receptor-G-protein binding site) is overexpressed.

In conclusion, using the single cell RT-PCR, we have surprisingly observed that the same PVR1 splice variants mRNA were expressed in 
somatotrophs and gonadotrophs while the coupling of PACAP to the transduction system was different in both cell types. This discrepancy could be explained by the fact that the effects of PACAP on anterior pituitary cells may depend not only upon the PACAP receptor type expressed, but also upon the expression of other components of intracellular pathways in these cells. The single cell RT-PCR technique described here could be useful for addressing such questions, since it allows the identification of multiple protein mRNA splice variants in single identified cells. This technique is, furthermore, potentially applicable to other mRNA species, for example those encoding signalling proteins such as enzymes (e.g. AC subtypes) and ion channels (Monyer \& Lambolez 1995, O’Dowd \& Smith 1996), as well as for other receptor molecules (Monyer \& Lambolez 1995, O’Dowd \& Smith 1996, Friend et al. 1997).

\section{ACKNOWLEDGEMENTS}

We wish to thank Laurent Journot for his invaluable advice during the setting up of the single cell RT-PCR technique in our laboratory, and for supplying us with the plasmids containing the cloned PVR1 splice variants. We would also like to thank Dominique Monnier for his help with the Southern blot analysis, and the group of Karl-Heinz Krause for providing the use of their patch-clamp/ microfluorimetry system. We are also very grateful to Nicholas Demaurex and Laurence Mery for their excellent comments on an earlier draft of this manuscript. L B B was supported by La Ligue Contre Le Cancer (France), and Swiss National Science Foundation grant No. 32-33514.92. This work was financed by Swiss National Science Foundation grant No. 31-45830.95.

\section{REFERENCES}

Arimura A 1992 Pituitary adenylate cyclase-activating polypeptide (PACAP): discovery and current status of research. Regulatory Peptides 37 287-303.

Bépoldin L, Journot L, Schlegel W \& Rawlings SR 1996 Expression of alternatively spliced forms of PACAP/VIP type 1 receptor in individual rat gonadotrophs detected by single cell RT-PCR. In Program of the 10th International Congress of Endocrinology, San Francisco, CA, p 436. (Abstract No. P2-128).

Chatterjee TK, Liu X, Davisson RL \& Fisher RA 1997 Genomic organization of the rat pituitary adenylate cyclaseactivating polypeptide receptor gene. Fournal of Biological Chemistry 272 12122-12131.

Christophe J 1993 Type I receptors for PACAP (a neuropeptide even more important than VIP?). Biochimica et Biophysica Acta 1154 183-199.
Culler MD \& Paschall CS 1991 Pituitary adenylate cyclaseactivating polypeptide (PACAP) potentiates the gonadotropinreleasing activity of luteinizing hormone-releasing hormone. Endocrinology 129 2260-2262.

Demaurex N, Rawlings SR, Krause KH, Jaconi MEE, Lew PD \& Schlegel W 1994 Combination of microfluorimetry of cytosolic $\mathrm{Ca}^{2+}$ and $\mathrm{pH}$ with patch clamp electrophysiological recordings in neutrophil granulocytes. Methods in Enzymology 238 308-320.

Friend KE, Bresson-Bépoldin L \& Rawlings SR 1997 Estradiol induces TERP-1 mRNA expression in lactotrophs from male rats. In Program of the 79th Annual Meeting of The Endocrine Society, Minneapolis, MN, USA, p 320 (Abstract No. P2-141).

Goth MI, Lyons CE, Canny BJ \& Thorner MO 1992 Pituitary adenylate cyclase activating polypeptide, growth hormone $(\mathrm{GH})$-releasing peptide and GH-releasing hormone stimulate $\mathrm{GH}$ release through distinct pituitary receptors. Endocrinology 130 939-944.

Gottschall PE, Tatsuno I, Miyata A \& Arimura A 1990 Characterization and distribution of binding sites for the hypothalamic peptide, pituitary adenylate cyclase activating polypeptide. Endocrinology 127 272-277.

Grynkiewicz G, Poenie M \& Tsien RY 1985 A new generation of $\mathrm{Ca}^{2+}$ indicators with greatly improved fluorescence properties. Fournal of Biological Chemistry 260 3440-3450.

Hamill OP, Marty A, Neher E, Sakmann B \& Sigworth FJ 1981 Improved patch clamp techniques for high-resolution current recording from cells and cell-free membrane patches. Pflugers Archiv 391 85-100.

Hezareh M, Journot L, Bépoldin L, Schlegel W \& Rawlings SR 1996a PACAP receptor subtypes, signal transducers and effectors in pituitary cells. Annals of the New York Academy of Sciences 805 315-327.

Hezareh M, Schlegel W \& Rawlings SR $1996 b$ PACAP and VIP stimulate $\mathrm{Ca}^{2+}$ oscillations in rat gonadotrophs through a PACAP/VIP type 1 receptor (PVR1) linked to a pertussis toxin-sensitive $\mathrm{G}$-protein and the activation of phospholipase C- $\beta$. Fournal of Neuroendocrinology 8 367-374.

Huang Z, Chen Y, Pratt S, Chen TH, Bambino T, Nissenson RA \& Schoback DM 1996 The N-terminal region of the third intracellular loop of the parathyroid hormone (PTH)/PTH-related peptide receptor is critical for coupling to cAMP and inositol phosphate $/ \mathrm{Ca}^{2+}$ signal transduction pathways. Fournal of Biological Chemistry 271 33382-33389.

Ishihara T, Shigemoto R, Mori K, Takahashi K \& Nagata S 1992 Functional expression and tissue distribution of a novel receptor for vasoactive intestinal polypeptide. Neuron $\mathbf{8}$ 811-819.

Lutz EM, Sheward WJ, West KM, Morrow JA, Fink G \& Harmer AJ 1993 The VIP $_{2}$ receptor: molecular characterisation of a cDNA encoding a novel receptor for vasoactive intestinal peptide. FEBS Letters 334 3-8.

McArdle CA \& Counis R 1996 GnRH and PACAP action in gonadotrophs: cross-talk between phosphoinositidase $\mathrm{C}$ and adenylyl cyclase mediated signaling pathways. Trends in Endocrinology and Metabolism 7 168-175.

Monyer H \& Lambolez B 1995 Molecular biology and physiology at the single-cell level. Current Opinion in Neurobiology 5 382-387.

Nudel U, Zakut R, Shani M, Neuman S, Levy Z \& Yaffe D 1983 The nucleotide sequence of the rat cytoplasmic beta-actin gene. Nucleic Acids Research 11 1759-1771.

O’Dowd DK \& Smith MA 1996 Single cell analysis of gene expression in the nervous system. Molecular Neurobiology 13 199-211. 
Poth K, Nutter J, Cuevas J, Parker MJ, Adams DJ \& Luetje CW 1997 Heterogeneity of nicotinic receptor class and subunit mRNA expression among individual parasympathetic neurons from rat intracardiac ganglia. Fournal of Neuroscience 17 586-596.

Rawlings SR 1996 Pituitary adenylate cyclase-activating polypeptide regulates $\left[\mathrm{Ca}^{2+}\right]_{i}$ and electrical activity in pituitary cells through cell type-specific mechanisms. Trends in Endocrinology and Metabolism 7 18-22.

Rawlings SR \& Hezareh M 1996 Pituitary adenylate cyclaseactivating polypeptide (PACAP) and PACAP/VIP receptors: actions on the anterior pituitary gland. Endocrine Reviews $\mathbf{1 7}$ 4-29.

Rawlings SR, Berry DJ \& Leong DA 1991 Evidence for localized calcium mobilization and influx in single rat gonadotropes. Fournal of Biological Chemistry 266 769-779.

Rawlings SR, Canny BJ \& Leong DA 1993 Pituitary adenylate cyclase-activating polypeptide regulates cytosolic $\mathrm{Ca}^{2+}$ in rat gonadotropes and somatotropes through different mechanisms. Endocrinology 132 1447-1452.

Rawlings SR, Demaurex N \& Schlegel W 1994 Pituitary adenylate cyclase-activating polypeptide increases $\left[\mathrm{Ca}^{2+}\right]_{\mathrm{i}}$ in rat gonadotrophs through an inositol trisphosphatedependent mechanism. Fournal of Biological Chemistry 269 $5680-5686$

Rawlings SR, Piuz I, Schlegel W, Bockaert J \& Journot L 1995 Differential expression of pituitary adenylate cyclaseactivating polypeptide/vasoactive intestinal polypeptide receptor subtypes in clonal pituitary somatotrophs and gonadotrophs. Endocrinology 136 2088-2098.

Robberecht P, Vertongen P, Velkeniers B, De Neef P, Vergani P, Raftopoulos C, Brotchi J, Hooghe-Peters E \& Christophe J 1993 Receptors for pituitary adenylate cyclase activating peptides in human pituitary adenomas. Fournal of Clinical Endocrinology and Metabolism 77 1235-1239.

Segre GV \& Goldring SR 1993 Receptors for secretin, calcitonin, parathyroid hormone $(\mathrm{PTH}) / \mathrm{PTH}$-related peptide, glucagon like peptide 1, growth hormone-releasing hormone, and glucagon belong to a newly discovered G-protein-linked receptor family. Trends in Endocrinology and Metabolism 4 309-314.

Spengler D, Waeber C, Pantaloni C, Holsboer F, Bockaert J, Seeburg PH \& Journot L 1993 Differential signal transduction by five splice variants of the PACAP receptor. Nature 365 170-175.

Tatsuno I, Somogyvari-Vigh A, Mizuno K, Gottschall PE, Hidaka H \& Arimura A 1991 Neuropeptide regulation of interleukin- 6 production from the pituitary: stimulation by pituitary adenylate cyclase-activating polypeptide and calcitonin gene-related peptide. Endocrinology 291 1797-1804.

Tsujii T, Ishizaka K \& Winters SJ 1994 Effects of pituitary adenylate cyclase-activating polypeptide on gonadotropin secretion and subunit messenger ribonucleic acids in perifused rat pituitary cells. Endocrinology 135 826-833.

Velkeniers B, Zheng L, Kazemzadeh M, Robberecht P, Vanhaelst L \& Hooghe-Peters EL 1994 Effect of pituitary adenylate cyclase-activating polypeptide 38 on growth hormone and prolactin expression. Fournal of Endocrinology $1431-11$.

Vertongen P, Velkeniers B, Hooghe-Peters E \& Robberecht P 1995 Differential alternative splicing of PACAP receptor in pituitary cell populations. Molecular and Cellular Endocrinology 113 131-135.

Villalba M, Bockaert J \& Journot L 1997 Pituitary adenylate cyclase-activating polypeptide (PACAP-38) protects cerebellar granule neurons from apoptosis by activating the mitogen-activated protein kinase (MAP kinase) pathway. Fournal of Neuroscience 17 83-90.

Zhong Y 1995 Mediation of PACAP-like neuropeptide transmission by coactivation of Ras/Raf and cAMP signal transduction pathways in Drosophila. Nature 375 $588-592$

RECEIVED 12 February 1998 